\title{
A NOÇÃo dE FÉ VERdAdEIRA NA OBRA POÉTICA DE PRUDÊNCIO: UMA ANÁLISE DO POEMA APOTHEOSIS
}

Ana Teresa Marques Gonçalves ${ }^{1}$

\begin{abstract}
Resumo
Num momento em que se buscava a consolidação dos princípios cristãos, levando os convertidos a terem práticas sociais próprias e diferenciadas das exercidas pelos gentios, Prudêncio oferece uma obra, denominada Apotheosis, na qual defende uma unicidade identitária para os cristãos, o que os faria identificar os erros das crenças indicadas como heréticas. Apresentando de forma poética os principais desvios na fé, o autor busca fornecer uma noção de fé verdadeira na qual os conversos poderiam se pautar para desenvolver as condutas corretas para aqueles que queriam seguir o Cristianismo e obter uma vida eterna após a morte. Trata-se de uma obra proselitista, que buscava fornecer cânones de exercício da fé cristã para os já convertidos e para os gentios em vias de conversão.
\end{abstract}

\section{Palavras-Chave}

Prudêncio; Apotheosis; Cristianismo; identidade; fé; heresia

1Professora Doutora, Universidade Federal de Goiás, Goiânia, Brasil. E-mail: anateresamarquesgoncalves@gmail.com 


\begin{abstract}
At a time when one was seeking to consolidate Christian principles, prompting converts to have their own social practices, differentiated from those exercised by Gentiles, Prudentius offers a work called Apotheosis, in which he advocates a uniqueness of identity for Christians, which would make them identify the errors of beliefs indicated as heretical. Presenting poetically the major departures in faith, the author seeks to provide a notion of true faith in which converts could begin to develop the right paths for those who wished to follow Christianity and obtain an eternal life after death. It is a proselytising work, which sought to provide exercise canons for the Christian faith for those already converted and for Gentiles in the process of conversion.
\end{abstract}

Keywords

Prudentius; Apotheosis; Christianity; identity; faith; heresy. 


\section{Uma obra proselitista}

Uma das características mais marcantes da obra prudentina é seu caráter proselitista. Apropriando-se dos cânones clássicos na produção de poemas em hexâmetros dactílicos, Aurélio Prudêncio Clemente, na passagem do IV para o V século d.C., legou-nos um farto corpus documental textual pelo qual podemos verificar que ele recebeu uma educação clássica baseada na leitura de obras pagãs de referência no sistema pedagógico latino. Em sua obra, identificam-se inúmeras referências formulaicas e/ou temáticas consistentes com as narrativas de Catulo, Horácio e Virgílio, autores de relevo na poesia latina. O que mais capta nossa atenção em seu estilo de produção é sua capacidade de se apropriar de cânones, referências, metáforas e figuras de linguagem clássicas e reutilizá-los na nobre tarefa de converter gentios em cristãos.

Buscando aproximar-se de seu público ouvinte/leitor, Prudêncio insere em seus poemas farto material mitológico, por sua vez já advindo da emulatio promovida pelos autores romanos do final da República e do Principado, no que concernia à releitura dos clássicos gregos, como os poemas de Homero. O deus cristão, por exemplo, em vários poemas prudentinos, passa a ser denominado de "o tonitruante" ou "o tonante" (Prudêncio. Apotheosis, III,173), como já haviam sido nos poemas pagãos o Zeus de Homero e o Júpiter de Virgílio. Mais do que mera referência ao passado ou uma simples adaptação ao gênero da poesia clássica, identificamos a utilização destas fórmulas, destes topoi por Prudêncio, como uma busca de se aproximar de um público que já conhecia estes artifícios e de se vincular a uma tradição em vias de ser ressignificada.

$\mathrm{Na}$ introdução do livro Interpreting Late Antiquity, cuja primeira edição se deu em 1999, seus editores G. W. Bowersock, Peter Brown e Oleg Grabar explicitam sua intenção de reunir num volume trabalhos que refletissem sobre acontecimentos dados entre 250 e 800 d.C., nos quais se verificaria a construção paulatina de um "mundo pós-clássico" (Bowersock; Brown; Grabar, 2001: 9). Não à toa, o primeiro capítulo da coletânea nos é oferecido por Averil Cameron e se intitula "Remaking the Past". Em suas linhas, a autora apresenta o período da Antiguidade Tardia, antes de tudo, como um período de intensa reelaboração das estruturas vindas de tempos anteriores, como um momento de produção do novo a partir do já conhecido, no qual a criatividade estava amalgamada com a releitura do que havia se demonstrado ser capaz de ser eficaz (Cameron, 2001: 7), promovido pela "reconciliação" dos cânones literários e retóricos antigos, clássicos, passados pelos processos pedagógicos que continuavam se efetivando, com a "fé cristã" e as novas necessidades proselitistas que se impunham (Cameron, 2001: 13). Ao invés de "rejeitar o passado pagão, 
este foi posto em uso" pelos cristãos, promovendo o que Cameron denomina de "renovatio" (Cameron, 2001: 14). Ainda segundo ela, a Antiguidade Tardia vivenciou uma "massa de experimentação", com novos modelos sendo criados e ajustados, num processo de criação de uma mitologia cristã e de desenvolvimento de novas identidades que implicava inevitavelmente na reapropriação do passado de acordo com as novas preocupações. O certo é que, durante a Antiguidade Tardia, o passado foi refeito de diferentes modos e pela inserção de um esforço contínuo (Cameron, 2001: 16).

Pensamos a Antiguidade Tardia como uma temporalidade na qual está se promovendo a criação de novas tradições, a partir do já existente e de sua reapropriação para a criação das identidades cristãs. Para os autores proselitistas cristãos, converter-se é se inserir numa nova seara de significados, é se reapropriar de um vocabulário pré-existente e utilizá-lo no complexo processo de conversão, no qual está estipulada a adesão a uma nova forma de vida, a uma nova filosofia de ação, a uma nova rede de sentidos. Tornar-se cristão seria, antes de tudo, refazer vínculos com a cultura pagã em novas possibilidades interpretativas.

Este complexo processo de adesão a uma "nova cultura", repleta de novas chaves de leitura da realidade, que implica na aceitação de outras práticas sociais, do abandono de certas crenças e na constituição de novos vínculos sociais e comunitários, permitiu a geração de obras cuja característica mais relevante é exatamente a mescla de referências ao passado, garantindo-lhes inserção na nova ordem sem rupturas drásticas para que o sentido do que é emitido não se perca, com a criação de novos sentidos para o que é reconhecido como relevante de ser mantido. A ética cristã não é tão subversiva frente à ética pagã.

Retomando mais uma vez o pensamento de Averil Cameron, no clássico livro Christianity and the Rhetoric of Empire: the Development of Christian Discourse, o processo de cristianização implicou antes de tudo na elaboração de novas representações feitas a partir de cânones retóricos clássicos e pagãos, por intermédio de sucessivas acomodações e apropriações (Cameron, 1994: 120 e p.189). A necessidade humana de exemplos de boas condutas sociais permanecia premente e os heróis antigos precisavam ser substituídos por novos modelos de interação comunitária, pois devemos sempre relembrar que filosofia e religio no mundo antigo eram antes de tudo formas de vida. Ser cristão era expressar uma fé por meio de uma conduta específica que marcava sua inserção social. 
Segundo Erich S. Gruen, na obra Heritage and Hellenism: The Reinvention of Jewish Tradition (1998), a tradição pode e deve ser reinventada constantemente para sobreviver à ação do tempo. O que parece cristalizado, na realidade é um longo e constante processo de integração e reintegração de vetores culturais. Valores são revistos, práticas reconstruídas, ações reinterpretadas à luz de novos simbolismos.

\section{O Autor e sua Obra}

Prudêncio nasceu em 348 d.C. Em sua obra faz referência ao governo de Juliano, o Apóstata (361 a 363 d.C.) e o aponta como Imperador durante sua infância (Prudêncio. Apotheosis, V, 450) (Rivero García, 1997: 35). Possivelmente hispânico, deve ter sido filho de pais cristãos, visto que nunca alude à sua conversão. Recebeu esmerada educação, na qual aprendeu as mais refinadas técnicas retóricas que pôs a serviço de sua produção literária. Seguiu carreira administrativa e ocupou a função de comes primi ordinis durante o governo de Teodósio I em Milão. Sabemos que visitou Roma entre 401 e 402 d.C. Porém, não sabemos nem quando nem onde morreu, mas que tinha 57 anos em 404 ou 405 d.C.

Apesar de ter produzido sua obra em latim, vários títulos que nos chegaram estão em grego e o seu relato está repleto de helenismos. A coleção poética prudentina nos chegou composta por nove títulos: Praefatio (um prefácio, uma apresentação de toda sua obra); Cathemerinon (conjunto de Hinos cristãos para serem usados cotidianamente pelos conversos); Apotheosis (seis refutações às heresias, também produzidas em forma de hinos); Hamartigenia (um poema sobre a origem do pecado); Psychomachia (poema sobre as contendas entre vícios e virtudes pelo domínio da alma humana); Contra Orationem Symmachi (dois livros contrários aos argumentos pagãos de Símaco, que defendia a permanência do altar da deusa Vitória na porta do Senado de Roma, cuja remoção foi ordenada por Graciano em 382 d.C.); Liber Peristephanon (Livro das Coroas, no qual 14 poemas sobre os heróis cristãos defendem o martírio corajoso); Tituli Historiarum ou Dittochaeon (48 epigramas de tema bíblico, 24 sobre o Antigo Testamento e 24 sobre o Novo Testamento); e De Opusculis suis Prudentius (que pode ser traduzido como: "Prudêncio acerca de suas próprias composições", pois da mesma forma que nos chegou um proêmio à sua obra, também nos chegou um epílogo, no qual o autor se apresenta como um cantor de Cristo, visto que não teria bons atos para ofertar a Deus nem riquezas que lhe capacitasse para oferecer esmolas, Prudêncio consagra seus versos, para que sua voz pudesse proclamar o nome de Cristo, afirmativa esta que tem levado os 
comentadores da obra prudentina a crer na recitatio de seus versos e até mesmo em vê-los como letras de canções).

Assim, a obra sobre a qual agora nos debruçamos, o longo poema Apotheosis, integra os chamados poemas doutrinais ou que buscam auxiliar na formação de uma ortodoxia cristã, definindo sistemas de crenças e defendendo algumas concepções a respeito do fenômeno da trindade (a abstrata e complexa ideia de Pai, Filho e Espírito Santo, e sua relação com os princípios do Cristianismo). Este poema prudentino é prova cabal do que André Chevitarese (2012) chama de Cristianismos, ou seja, de que nos primórdios da tentativa de constituição de um pensamento cristão, mesmo após a ocorrência do Concílio de Nicéia, dirigido pelo Pontifex Maximus Constantino em 325 d.C., abundavam pensamentos e ideias conflitantes, complementares e diversas no mundo cristão. Não havia ainda sido constituído um sistema de práticas e representações único a ser abordado pelos conversos. Isto permite que Prudêncio crie uma obra baseada nos cânones poéticos clássicos, na qual a beleza e a fluidez de sentido se intercalam em importância ao ideário defendido, integrando forma e conteúdo, para defender algumas concepções trinitárias frente a outras existentes em seu tempo e que por ele são definidas como posturas heréticas, concebidas como interpretações equivocadas dos textos bíblicos sagrados.

\section{As Heresias na Concepção Prudentina}

Aliar-se a uma heresia, a um erro de interpretação, a uma conduta desviante causada por um equívoco da ordem do pensamento, seria para Prudêncio o afastar-se da ordem racional de uma forma de reflexão. Mais do que um pecado, como a heresia era vista por vários homiliastas, como Basílio de Cesareia ou João Crisóstomo, a heresia na visão poética prudentina se inseriria na ordem do equívoco de deliberação acerca de um discurso, que infundiria crenças errôneas. Os seis hinos e dois prefácios que compõem a Apotheosis buscam desfiar argumentos racionais, no seio da estipulação de uma ratio cristianizada, para combater certos princípios julgados equivocados frente a outros defendidos como mais adequados ao pensamento cristão.

Os hinos são antes de tudo disputationes no sentido da oratória clássica, ou seja, disposições argumentativas pelas quais se apresenta um problema e sucessivamente se constrói de forma perolada uma solução. Nesta obra específica, mais do que converter gentios, Prudêncio busca uma reconversão, isto é, que os já cristianizados se afastassem de ideias 
equivocadas e passassem a professar a fé verdadeira, baseada na constituição de pressupostos mais adequados a uma interpretação específica, que buscava se tornar canônica/hegemônica do texto bíblico. Este poema prudentino invoca o longo processo de formulação da denominada ortodoxia cristã, no qual vários posicionamentos foram indicados como heréticos, contrários ao cânone que ainda estava em fase de elaboração.

O próprio título com o qual o poema nos chegou, Apotheosis, já indica a partir do vocábulo grego a noção de transformação, de assumir uma nova forma, de mudar a constituição de algo a partir de um ritual ou de uma prática intensa e recorrente. Um ser elabora e sofre uma apoteose, que é um processo no qual o ser é agente e receptor da mudança, exatamente como no processo de conversão ao cristianismo. Mas a mudança pode ser implementada a partir de postulados falsos e premissas falaciosas. E é desta forma que Prudêncio encara as heresias, como uma conversão realizada a partir de pressupostos equivocados, que podem ser abandonados, gerando uma verídica conversão, pelo reconhecimento da falsidade até então infundida. Por isso, Prudêncio começa o poema com algumas definições: o que é Deus e como ele se manifesta na Trindade.

No primeiro prefácio, Prudêncio define que Deus é uma só substância que se apresenta aos homens por meio de três manifestações: o Pai é o poder, o filho é a sabedoria e o verbo é o Espírito Santo, e crer nisto é ato de fé e ação inquestionável (Prudêncio. Apotheosis, I, 1-4). Deste modo, o poder só se estabelece por intermédio da sabedoria, utilizando o verbo como instrumento de comando. No segundo prefácio, define que o cristianismo é uma secta, vocábulo latino que indica sistema de crenças, mas também escola ou doutrina filosófica, ou seja, conjunto de princípios que devem ser professados pelos aderentes. Além disso, defende que o cristianismo se trata da fé correta e que se deve evitar confusões, disputas caluniosas, astúcias disfarçadas e perversões lingüísticas na estipulação de seus princípios. A língua, na concepção prudentina, "é uma pedra cravada", que pode derrubar ou pode orientar, dependendo do uso que se faça dela (Prudêncio. Apotheosis, II, 1-36).

O primeiro hino busca desfazer o engano dos patripasianos, ou seja, os que professavam a heresia também conhecida como modalismo ou monarquianismo. Estes defendiam que a Trindade era composta por três manifestações ou modos de um deus único, o que supunha que o Pai ao estar encarnado na figura de Cristo também havia sofrido a paixão na cruz. Conhecemos esta comunidade herética pela obra de Tertuliano, Contra Praxeas, do III século d.C., na qual cita-se esta heresia e seus dois principais defensores: Noeto e Praxeas. Prudêncio começa o hino com 
uma pergunta: "Deus é suscetível de sofrimento ?" (Prudêncio. Apotheosis, III, 6). Sua resposta negativa é sustentada por três argumentos simples: 1) ninguém pode ver deus, então ninguém pode afirmar que ele sofreu na cruz; 2) o filho é que se expôs ao olhar humano, pois "a majestade em estado puro é infinita e não penetra os olhares se não adquire forma e limites" (Prudêncio. Apotheosis, III, 25-27); 3) o pai invisível gerou um filho visível, que é quem executa os milagres, e é impossível sofrer paixão quem não nasceu (Prudêncio. Apotheosis, III, 119120). Deste modo, o poeta afasta-se de qualquer relato cosmogônico e/ou teofânico, como os que marcaram a Antiguidade, como por exemplo, a Teogonia de Hesíodo ou As Metamorfoses de Ovídio.

Para Prudêncio, é importante enfatizar a impossibilidade de ver Deus, pois isto garante sua premissa racional trinitária, mas também o aproxima de pensamentos clássicos conhecidos. Lembremos que Zeus, na mitologia grega, também é luz e calor, como para os cristãos, mas ao se fazer ver frente à insistência de Sêmele, filha de Cadmo e Harmonia e mãe de Dioniso, acaba por queimá-la. Qualquer tentativa seja pagã ou cristã de interagir com a divindade suprema em sua forma primeva é perigosa para os humanos.

\section{Os Erros de Interpretação e de Conduta}

E desta forma vão sendo construídos os hinos, com a apresentação de uma premissa julgada errônea, pela falsidade da interpretação dos textos bíblicos, e o elenco de argumentos considerados simples e irrefutáveis pelo poeta cristão, que crê ser a sua interpretação dos textos sagrados a mais verdadeira, por ser a mais lógica e a mais racional.

No segundo hino, Prudêncio combate os unionitas ou sabelianos, que entendiam a Trindade como simples manifestação de uma mesma pessoa. Trata-se do único herege nomeado no poema, Sabélio, alcunhado de "profanador de Cristo" (Prudêncio. Apotheosis, IV, 179-180) e inspirador do poema que retém o maior número de referências a entidades da Antiguidade Clássica. Prudêncio afirma que Sabélio tirou de deus "a honra de ser pai e sua capacidade de gerar linhagem" (Prudêncio. Apotheosis, IV, 186), atividade primordial para qualquer ser de essência masculina na Antiguidade. O poema prudentino fornece, então, ao leitor/ouvinte uma gama de referências a Saturno, Juno, Apolo, Anúbis, entre outros, para referendar que o trono do céu está ocupado apenas por um único soberano: o deus cristão. Todo resto é equívoco. Cita, então, as extravagantes obras do "barbudo Platão" e os retorcidos enganos do 
"tecelão Aristóteles" (Prudêncio. Apotheosis, IV, 200-204), que usando de razão e lógica não conseguiram negar a existência de um governo supremo. Para Prudêncio, só "compreendemos as palavras dos heróis antigos e suas profecias após a contemplação de Cristo" (Prudêncio. Apotheosis, IV, 236-237). Assim, a chave de entendimento do passado só se dá com a chegada de Cristo; são suas ações como a encarnação da sabedoria do deus cristão que dá sentido a tudo que foi dito e professado no passado clássico. Desta maneira, Prudêncio cria uma nova chave interpretativa para todos os relatos do seu passado: a lógica implantada pelo advento da fé cristã.

Os gentios são alcunhados de "portadores de incenso", "adoradores de imagens de pedra e madeira" e "adoradores de Deucaliões" (Prudêncio. Apotheosis, IV, 292-294), relembrando que na mitologia grega Deucalião, filho de Prometeu, junto com sua esposa e prima Pirra, filha de Epimeteu e Pandora, foram os únicos humanos que sobreviveram ao dilúvio enviado por Zeus na Idade do Bronze. Ao se sentirem solitários, pedem a Zeus novos companheiros. Zeus indica que atirem pedras por sobre o ombro e destas pedras surgiram novos homens e mulheres. Deste modo, no poema prudentino, os pagãos são seres que vêm da terra árida e pedregosa e não da luz e do verbo divinos, como os cristãos, que passam assim a serem vistos como possuidores de uma nova natureza e de uma nova identidade cultural. Para Prudêncio, os sabelianos se aproximavam dos pensamentos pagãos ao não perceberem que é fundamental para a criação de uma especificidade dos conversos que a natureza de sua criação se modifique. Os cristãos deveriam crer que eram a imagem de Cristo e que este era, por sua vez, a imagem do Pai, por isso Pai, Filho e Espírito Santo não poderiam ser uma unicidade plena.

No terceiro hino, Prudêncio se insurge contra os judeus, vistos como divulgadores de uma heresia, de um erro de interpretação das Escrituras. Pergunta-se: como puderam renegar a natureza divina de Cristo ? No relato prudentino, os judeus são cegos, blasfemadores e realizam rituais criminosos (Prudêncio. Apotheosis, V, 354-355). São também surdos e ignorantes, pois não conseguem entender o que está estipulado "pelas plumas hebréias, pela abundância do que é narrado de forma ática e pela eloqüência da língua ausônia" (Prudêncio. Apotheosis, V, 379-381), aludindo de forma poética às três versões sucessivas dos textos sagrados (em aramaico, grego e latim). No meio do hino, pergunta-se mais uma vez: "Judéia, esta voz não chegou até teus ouvidos ? Chegou sim, mas não penetrou no teu espírito carente de luz, foi detida nos primeiros umbrais e acabou fugindo de ti" (Prudêncio. Apotheosis, V, 423-425). Então, Prudêncio se refere ao abandono dos oráculos, citando 
diretamente Delfos e os Livros Sibilinos (Prudêncio. Apotheosis, V, 438441), e afirma:

Perdeu Dodona (oráculo de Zeus no Épiro) mentirosa suas enlouquecedoras emanações, chora Cumas (sibila na Campânia) já emudecida a morte de seus oráculos e Amon não dá mais respostas [...]. O Capitólio de Rômulo lamenta que Cristo reluz como um deus para seus Príncipes e que seus templos tenham sido destruídos por ordem de seus Imperadores. Já suplicante a púrpura do mandatário enéada se prostra ante o umbral de Cristo e se adora o estandarte da cruz (Prudêncio. Apotheosis, V, 442-449).

Este é o grande ponto de questionamento deste hino: como os pagãos acabaram por reconhecer a glória e a luminosidade do deus cristão, enquanto os judeus permaneceram cegos e surdos aos grandes feitos ? Não à toa é o mais extenso hino do poema, pois o tom triunfalista se expande um pouco ante a recusa judaica em perceber a fé verdadeira. Com isso, Prudêncio afirma que os judeus fazem seus cultos através de "bisbiseos", vocábulo latino para sussurros, como os pagãos, ou seja, de forma pouco enfática, discreta, quase envergonhada. Pois Cristo teria abolido:

Os sábados terrenos (sábado judaico) para elevar os mortais a sábados eternos e brilhou sobre os povos, resplandeceu por cima dos reis, possuiu o mundo, obrigou Roma, dona do Império, a render-se e dominou as imagens dos deuses da rocha Tarpeia [...]. Não estão destruídos os muros do Templo de Salomão, levantados por mãos humanas, e destruídos seus metais ? (Prudêncio. Apotheosis, V, 505-514).

E responde Prudêncio que o verdadeiro, eterno e indestrutível templo é o verbo que se fez carne. Enquanto Tito, Imperador Romano, filho de Vespasiano e irmão de Domiciano, manteve a lição já impetrada pelas tropas de Pompeu aos judeus, dispersando os hebreus por todo o Império, os cristãos prudentinos são pintados como indestrutíveis por empunharem a força do novo credo (Prudêncio. Apotheosis, V, 525-548).

No quarto hino, Prudêncio indica os erros homuncionitas ou ebionitas (do vocábulo hebreu ebionim, pobres), praticado por alguns judeus convertidos que reconheciam Cristo como um dos profetas anunciados por Moisés ou Isaías, mas homem e não deus, o que mais uma vez desorganizava o pensamento trinitário. $O$ poeta começa $o$ hino informando que estes heréticos se aproximavam da loucura judaica ao reconhecerem a piedade de Cristo, como bom filho, mas ao negarem sua majestade (Prudêncio. Apotheosis, VI, 553-557). Muito interessante esta apropriação prudentina dos termos latinos pietas e maiestas, visto que em sua concepção os ebionitas conseguiam observar o afeto e o respeito das relações familiares exercidas entre Cristo e o Pai, mas negavam a 
majestade, o aspecto religioso da natureza superior dos tocados pela divindade. Para os ebionitas, Cristo não detinha numem ou genius, um poder ou essência divinos, o que era inconcebível para Prudêncio. Este poeta passa, então, a defender a virgindade de Maria e a ação dos anjos junto aos humanos, passando a denominar Cristo de Emanuel, o "deus conosco" (Prudêncio. Apotheosis, VI, 606), capaz de realizar vários milagres por permissão e presença divina. O poema passa a relatar de forma poética vários milagres oferecidos por Cristo, como multiplicar alimentos, aplacar tormentas, recobrar a visão, ressuscitar mortos (Prudêncio. Apotheosis, VI, 743). Neste último caso, é Lázaro o personagem épico por excelência que retorna do Tênaro, cabo ao sul do Peloponeso onde se localizaria na mitologia grega uma das entradas do Hades. No hino prudentino, Cristo vence os interditos pagãos, sendo mais hábil que Orfeu e Odisseus, e traz para o mundo dos vivos um ser antes vencido pela morte.

No quinto hino, Prudêncio tece comentários a respeito da natureza da alma e questiona os que não acreditam que em cada corpo corruptível habita uma alma incorruptível, criada pelo deus cristão como um pneuma, um sopro, "uma sombra de Deus" (Prudêncio. Apotheosis, VII, 798). Foi moldada pela boca de Deus, mas enquanto o corpo é real, a alma é uma imitação do real (simulacro):

(A alma) é semelhante a Deus, porque não se esgota em tempo algum, porque é sábia, capaz de justiça e como rainha do mundo manda, ainda que antes de mandar observa, suspeita, prevê, fala, é artífice de palavras e costumes, é dotada de mil habilidades e busca recorrer ao céu com seu juízo (Prudêncio. Apotheosis, VII, 801-807).

Sendo assim, os heréticos cometem erro com a alma, pois não a entendem bem, não a compreendem, não a escutam. É a alma humana, no pensamento prudentino, o receptáculo da inteligência e da hermenêutica, e sem a contemplação devida de seus ensinamentos cometem-se erros de interpretação das Escrituras.

No sexto e último hino, Prudêncio se insurge contra os marcionitas e fantasmáticos, ou seja, os que postulavam que Cristo teve um corpo somente aparente, sem fundamento real. Assim, eles não só colocavam em dúvida a questão trinitária como questionavam a paixão e a ressurreição corporal de Jesus. $O$ primeiro hino do poema ressignifica o surgimento de Cristo; este último redimensiona a morte de Cristo. Afirma Prudêncio que se o corpo de Cristo era somente aparência, então Deus era um enganador, um embusteiro, e os cristãos não podem conviver com este anátema de serem fiéis a um deus astucioso e mentiroso. Ressalta Prudêncio: "Pois se faz algo com engano, isto não é deus" (Prudêncio. 
Apotheosis, VIII, 975). E busca argumentos nos Evangelhos de Mateus e Lucas: Cristo descendia da carne de antepassados humanos, que procedem da semente de Davi e foi herdeiro de seu sangue (Prudêncio. Apotheosis, VIII, 998-1002). Assim: "Cristo é nossa carne, por mim se acaba e por mim renasce. Me acabo pela morte, que é minha, pela virtude de Cristo renascido" (Prudêncio. Apotheosis, VIII, 1047-1049). Cristo é pintado como o que desdenha do horror da tumba e Prudêncio encerra o poema com versos que defendem a ressurreição de Cristo e dos homens após o Juízo Final, "que retornarão com os membros restaurados" (Prudêncio. Apotheosis, VIII, 1074).

Esta parte final do hino é bastante interessante, pois Prudêncio defende que mesmo os que morreram devido a enfermidades terríveis, que destruíram nacos de carne, e os que perderam membros do corpo ao longo da vida, receberão a ressurreição com os corpos recompostos de forma plena. Cristo venceu a morte e sua corrupção para si e para todos os conversos, ele afirma. Nesta peroratio do poema, o autor resolve um dilema clássico. Lembremos de Títono, irmão mais velho de Príamo, rei de Tróia, por quem Eos, o amanhecer, irmã de Selene, a lua, e de Hélios, o sol, apaixonou-se. Ela pede a Zeus a imortalidade do amante, mas se esquece de solicitar a eterna juventude, o que ocasiona uma velhice horrível para o herói, que acaba aprisionado num quarto escuro no qual se transforma numa cigarra. No pensamento cristão prudentino, o dilema da ação de Geras se desfaz, visto que mesmo que durante o tempo de vida na Terra o cristão tenha seu corpo maculado por acidentes ou enfermidades, o processo mágico da ressurreição lhe garantiria a recomposição dos membros corpóreos, pela ação do Verbo e do próprio Cristo.

\section{Considerações Finais}

Portanto, da concepção à morte, o Cristo prudentino demonstra a sabedoria do Pai e garante a veracidade do pensamento trinitário. Prudêncio dá, assim, sua contribuição para a construção da fé verdadeira, que não poderia conter em si pressupostos que se auto-excluíam. A garantia da veracidade para a fé cristã impedia a dúvida. Os argumentos que a sustentavam, qual pilares de uma construção arquitetônica, deveriam ser fortes e profundos. Não poderiam ser abalados por terremotos lingüísticos ou tsunamis interpretativas. Deveriam ser postos à prova e sustentados racionalmente, no interior da ordem do discurso cristão ainda em construção. 
Uma fé forte partia da crença sem questionamentos, mas também de argumentos factíveis e passíveis de entendimento pelos crentes, pelos que professavam a fé e que buscavam novos conversos. Só uma fé íntegra e sem divisões internas poderia conquistar novos adeptos, segundo a concepção poética prudentina expressa no documento analisado. Mais do que comunicar os princípios de vida dos cristãos, esta obra prudentina permite a resolução de conflitos, usando a lógica e a poética cristianizadas para a divulgação do que o autor julgava ser a fé verdadeira.

\section{Fontes Antigas}

BÍBLIA SAGRADA. Nova Versão Internacional. São Paulo: Vida, 2003.

PRUDÊNCIO. Obras. Trad. Luis Rivero García. Madrid: Gredos, 1997. V.1 e 2 .

Press, 1993. (Loeb).

Apotheosis. Trad. J. H. Thomas. London: Harvard University

Referências Bibliográficas

BOWERSOCK, G. W. Hellenism in Late Antiquity. Ann Arbor: The University of Michigan Press, 2008.

; BROWN, P; GRABAR, O. (eds.). Interpreting Late Antiquity: Essays on the Postclassical World. London: Harvard University Press, 2001.

BOYARIN, Daniel. Dying for God. Califórnia: Stanford University Press, 1999.

CAMERON, Averil. Remaking the Past. In: BOWERSOCK, G. W.; BROWN, P; GRABAR, O. (eds.). Interpreting Late Antiquity: Essays on the Postclassical World. London: Harvard University Press, 2001. p.1-20.

Christianity and the Rhetoric of Empire: The Development

of Christian Discourse. Berkeley: University of California Press, 1994.

CHEVITARESE, André L. Cristianismos. Rio de Janeiro: Ed. Sesc, 2012.

CROSSAN, Dominic. O Nascimento do Cristianismo. São Paulo: Paulinas, 2004. 
GRUEN, Erich S. The Hellenistic World and the Coming of Rome. Berkeley: University of California Press, 1984.

Press, 2011. . Rethinking the Other in Antiquity. Princeton: University . Heritage and Hellenism: The Reinvention of Jewish Tradition. Berkeley: University of California Press, 1998. - Cultural Identity in the Ancient Mediterranean. Los Angeles: Getty Publications, 2011.

HOPE, Valerie M.; MARSHALL, Eireann (eds.). Death and Disease in the Ancient City. London: Routledge, 2000.

HOPKINS, Keith. A World Full of Gods: The strange Triumph of Christianity. New York: Plume, 2001.

KENNEDY, George A. Classical Rhetoric and its Christian and Secular Tradition from Ancient to Modern Times. London: The University of North Carolina Press, 1999.

MARINCOLA, John. Authority and Tradition in Ancient Historiography. Cambridge: University Press, 1997.

RIVERO GARCÍA, Luis. Introdução e Notas. In: Prudêncio. Obras. Trad. Luis Rivero García. Madrid: Gredos, 1997. V.1 e 2, p.7-147.

ROPS, Daniel. A Igreja dos Apóstolos e dos Mártires. São Paulo: Quadrante, 1988.

VERNANT, Jean-Pierre. El Individuo, la Muerte y el Amor en la Antigua Grecia. Barcelona: Paidós, 2001. . A Travessia das Fronteiras. São Paulo: EDUSP, 2009.

WEBB, Ruth. Ekphrasis, Imagination and Persuasion in Ancient Rhetorical: Theory and Practice. Surrey: Ashgate, 2009. 